\title{
Epiphytic bacterial community composition on two common submerged macrophytes in brackish water and freshwater Melanie Hempel*1, Maja Blume ${ }^{1,2}$, Irmgard Blindow ${ }^{2}$ and Elisabeth M Gross ${ }^{1}$
} Address: ${ }^{1}$ Limnology, Department of Biology, University of Konstanz, PO Box 659, D-78457 Konstanz, Germany and 2Biological Station of
Hiddensee, University of Greifswald, D-18565 Kloster, Germany

Email: Melanie Hempel* - Melanie.Hempel@uni-konstanz.de; Maja Blume - MajaBlume@gmx.net; Irmgard Blindow - blindi@unigreifswald.de; Elisabeth M Gross - Elisabeth.Gross@uni-konstanz.de

* Corresponding author

Published: 10 April 2008

BMC Microbiology 2008, 8:58 doi:10.1 |86/147|-2180-8-58
Received: 20 November 2007

Accepted: 10 April 2008

This article is available from: http://www.biomedcentral.com/|47|-2/80/8/58

(c) 2008 Hempel et al; licensee BioMed Central Ltd.

This is an Open Access article distributed under the terms of the Creative Commons Attribution License (http://creativecommons.org/licenses/by/2.0), which permits unrestricted use, distribution, and reproduction in any medium, provided the original work is properly cited.

\begin{abstract}
Background: Plants and their heterotrophic bacterial biofilm communities possibly strongly interact, especially in aquatic systems. We aimed to ascertain whether different macrophytes or their habitats determine bacterial community composition. We compared the composition of epiphytic bacteria on two common aquatic macrophytes, the macroalga Chara aspera Willd. and the angiosperm Myriophyllum spicatum L., in two habitats, freshwater (Lake Constance) and brackish water (Schaproder Bodden), using fluorescence in situ hybridization. The bacterial community composition was analysed based on habitat, plant species, and plant part.
\end{abstract}

Results: The bacterial abundance was higher on plants from brackish water $\left[5.3 \times 10^{7}\right.$ cells $(\mathrm{g}$ dry mass) $\left.)^{-1}\right]$ than on plants from freshwater [1.3 $\times 10^{7}$ cells $\left.(\mathrm{g} \text { dry mass })^{-1}\right]$, with older shoots having a higher abundance. The organic content of freshwater plants was lower than that of brackish water plants ( 35 vs. $58 \%$ ), and lower in C. aspera than in M. spicatum ( $4 \mathrm{I}$ vs. $52 \%$ ). The content of nutrients, chlorophyll, total phenolic compounds, and anthocyanin differed in the plants and habitats. Especially the content of total phenolic compounds and anthocyanin was higher in M. spicatum, and in general higher in the freshwater than in the brackish water habitat. Members of the CytophagaFlavobacteria-Bacteroidetes group were abundant in all samples (5-35\% of the total cell counts) and were especially dominant in M. spicatum samples. Alphaproteobacteria were the second major group (3-17\% of the total cell counts). Betaproteobacteria, gammaproteobacteria, and actinomycetes were present in all samples ( 5 or $10 \%$ of the total cell counts). Planctomycetes were almost absent on M. spicatum in freshwater, but present on $C$. aspera in freshwater and on both plants in brackish water.

Conclusion: Bacterial biofilm communities on the surface of aquatic plants might be influenced by the host plant and environmental factors. Distinct plant species, plant part and habitat specific differences in total cell counts and two bacterial groups (CFB, planctomycetes) support the combined impact of substrate (plant) and habitat on epiphytic bacterial community composition. The presence of polyphenols might explain the distinct bacterial community on freshwater $M$. spicatum compared to that of $M$. spicatum in brackish water and of $C$. aspera in both habitats. 


\section{Background}

In aquatic systems, bacteria occur often associated with surfaces, e.g. in biofilms or on lake or marine snow [1]. Biofilm associated bacteria are most abundant at intermediate nutrient availability while either low or high nutrient conditions favour planktonic growth of bacteria [2]. Biofilms are not only formed on abiotic surfaces but also on living organisms such as aquatic plants and algae.

In freshwater and marine habitats, bacteria associated with cyanobacterial blooms, diatom blooms, phytoplankton [3], lake snow [4], and bacterioplankton [5,6] have been investigated. Betaproteobacteria occur almost exclusively in freshwater but not in saline habitats, while alphaproteobacteria are more abundant in marine than in freshwater samples [5]. Alphaproteobacteria dominate the planktonic bacteria in the North Sea, followed by the Cytophaga-Flavobacteria-Bacteroidetes (CFB) group, and all groups of bacteria display a seasonal succession [7]. Diverse bacterial communities dominate in cyanobacterial blooms, including members of the CFB group and betaproteobacteria [8]. Mainly members of the CFB group and alphaproteobacteria, especially Roseobacter, are attached to marine diatoms $[9,10]$. Members of the CFB group and alpha-, beta-, and gammaproteobacteria have been identified by molecular methods on the chlorophytes Desmidium devillii, Hyalothexca dissliens, and Spondylosium pulchrum [11]. In general, the bacteria associated with diatoms and some chlorophytes that have been studied are mostly heterotrophic. In contrast, information about bacterial biofilms on aquatic macrophytes is scarce. A general overview and comparisons of attached and planktonic bacterial communities in freshwater and marine habitats is given in $[12,13]$ and references therein.

Submerged macrophytes are, in addition to algae, the main primary producers in lakes; they structure the littoral zone and prevent resuspension of sediments, thus enabling clear water states [14]. The freshwater macrophytes Myriophyllum spicatum and Chara globularis, and possibly also other Chara species, produce secondary compounds such as polyphenols and cyclic sulfur compounds, which exert allelopathic activity against algae and cyanobacteria $[15,16]$. Antibacterial cyclic quaternary amines have been isolated from $C$. globularis [17]. Hydrolysable polyphenols of $M$. spicatum, especially tellimagrandin II, inhibit photosystem II of cyanobacteria [18]. Plant polyphenols may have antimicrobial activity, but some bacteria may also overcome polyphenol-based plant defences [19].

Not only secondary metabolites but also nutrients possibly affect biofilm density and composition. Depending on their life cycle stage, macrophytes may release low to substantial amounts of macronutrients [20], and at times high concentrations of micronutrients [21]. Especially older plant parts may leak both organic compounds and inorganic nutrients [22]. Nutrient conditions affect the impact of submerged macrophytes on bacterioplankton: Vallisneria americana has a positive impact on bacterioplankton density under high $\mathrm{NH}_{4}{ }^{+}$conditions, but a neutral or negative impact when $\mathrm{NH}_{4}{ }^{+}$is limiting [23].

Biofilms can be both beneficial and detrimental for submerged macrophytes. On the positive side, epiphytic biofilms provide organic compounds and carbon dioxide to the macrophytes and enhance nutrient recycling [24]. Further, the biofilm bacteria Roseobacter gallaciencis and Pseudoalteromonas tunicata that colonize the marine alga Ulva australis produce compounds against fouling organisms [25], and axenic Ulva linza require bacteria to restore the typical growth form, and some bacteria even enhance the algal growth rate $[26,27]$. Negative impacts on submerged macrophytes could arise from increased shading by thick biofilms and possibly also from pathogenic bacteria present in the biofilm. Macroalgae can also have negative effects on epiphytic bacteria. For instance, bacterial colonization of the marine red algae Bonnemaisonia hamifera and Delisea pulchra is inhibited by algalreleased secondary metabolites $[28,29]$. These furanones also affect the swarming motility of Serratia liquefaciens [30] and indirectly affect larval attachment [31]. Whether or not such chemical interactions between plants and bacteria are important for biofilm density and community composition on aquatic macrophytes is unknown. The only study addressing microbial diversity on M. spicatum showed that the biofilm was dominated by gammaproteobacteria and members of the CFB group [32]. Bacterial epiphytes of $C$. aspera have not been described before.

Given that a strong interaction might exist between plants and their associated heterotrophic biofilm, especially in aquatic systems, we questioned whether different macrophytes (substrate, plant age) or the respective habitat determines bacterial community composition. We selected two common, allelochemically active, submerged macrophytes, Chara aspera and Myriophyllum spicatum, sampled in freshwater (Lake Constance) and brackish water (Schaproder Bodden). We identified plant species, plant age, and habitat-specific differences and similarities of the bacterial density and community composition.

\section{Results}

The two plant species, each from two different habitats, exhibited distinct morphological and chemical characteristics. The organic content of the plants of each species and from each habitat differed, but the upper or lower parts of each plant sampled did not differ in organic content (Figure 1; 3-way ANOVA, Table 1). Chara aspera had a lower organic content $(40.9 \% \pm 14.4$, mean $\pm S D, n=$ 
12) than Myriophyllum spicatum $(51.7 \% \pm 11.6$, mean \pm $\mathrm{SD}, \mathrm{n}=12)$. Freshwater plants had a much lower organic content $(35.1 \% \pm 9.4$, mean $\pm \mathrm{SD}, \mathrm{n}=12)$ than brackish water plants $(57.5 \% \pm 6.6$, mean $\pm S D, n=12)$. Only a marginal interaction of plant $\times$ habitat was found $(\mathrm{p}=$

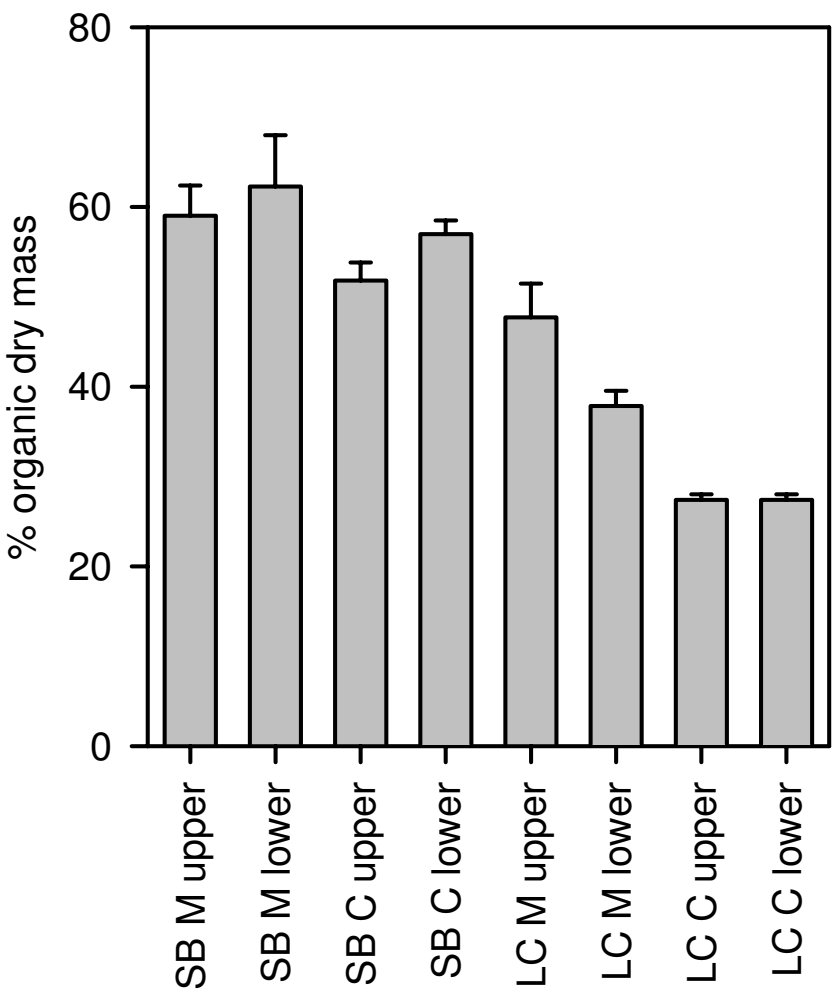

Figure I

Proportion of organic dry mass in plant samples collected at all sites. SB: Schaproder Bodden, LC: Lake Constance, C: Chara aspera, M: Myriophyllum spicatum; upper and lower indicate plant parts analysed; $\mathrm{n}=3$; error bars indicate SE.

Table I: Statistical analysis
0.079), owing to a larger difference in organic content of $C$. aspera from the two sites than that of M. spicatum. The significant interaction term between habitat and plant part is due to the observed differences of plant parts in Lake Constance; the organic content of the plant parts did not differ in plants from Schaproder Bodden.

Myriophyllum spicatum contained more phenolic compounds than $C$. aspera [97-173 $\mathrm{mg}$ (g dry mass) ${ }^{-1}$ vs. $<1$ mg (g dry mass)- ${ }^{-1}$; Table 2] and $M$. spicatum from Lake Constance had a slightly higher polyphenol content than M. spicatum from Schaproder Bodden [apices: $173 \pm 21$ $\mathrm{mg}$ (g dry mass) $)^{-1}$ and $120 \pm 33 \mathrm{mg}$ (g dry mass) ${ }^{-1}$, respectively; Student's $t$-test: $\mathrm{P}=0.02$ ]. Also the anthocyanin content was much higher in $M$. spicatum than in $C$. aspera. In both habitats, the anthocyanin content of $C$. aspera was $<0.1 \mathrm{mg}$ (g dry mass) ${ }^{-1}$; the anthocyanin content of $M$. spicatum from Schaproder Bodden was slightly lower than that of $M$. spicatum from Lake Constance [approx. $0.5 \mathrm{mg}$ (g dry mass) $)^{-1}$ vs. $1.0 \mathrm{mg}$ (g dry mass) ${ }^{-1}$; Student's $t$-test: $\mathrm{P}=0.005$, Table 1]. The chlorophyll $a$ and $b$ contents were highest in the apical shoots and upper leaves of M. spicatum from Lake Constance (Table 2).

The carbon content (Table 2) of $C$. aspera was about half of that of M. spicatum, possibly in part owing to the overall lower organic dry mass of the former. Chara aspera also contained less nitrogen and phosphorus per g dry mass than $M$. spicatum when whole plants were considered. The $\mathrm{C} / \mathrm{N}$ molar ratio ranged from about 15 in apices of $M$. spicatum fromLake Constance to 31 in stems of $M$. spicatum from Schaproder Bodden. The $\mathrm{C} / \mathrm{P}$ molar ratio ranged from 436 in apices of $M$. spicatum to more than 1373 in C. aspera from Lake Constance.

We determined the bacterial abundance based on plant dry mass since there are no reliable surface area-to-biomass ratios for $M$. spicatum and $C$. aspera from the two

\begin{tabular}{|c|c|c|c|c|c|c|c|c|c|c|c|}
\hline \multirow[b]{2}{*}{$\begin{array}{l}\text { Source of } \\
\text { variation }\end{array}$} & \multirow[b]{2}{*}{ DF } & \multicolumn{2}{|c|}{$\%$ Plant organic matter } & \multicolumn{2}{|c|}{ Ash-free dry mass } & \multicolumn{2}{|c|}{ Total bacterial cell counts } & \multicolumn{2}{|c|}{ Planctomycetes } & \multicolumn{2}{|c|}{ CFB } \\
\hline & & $\mathbf{F}$ & $\mathbf{P}$ & $\mathbf{F}$ & $\mathbf{P}$ & $\mathbf{F}$ & $\mathbf{P}$ & $\mathbf{F}$ & $\mathbf{P}$ & $\mathbf{F}$ & $\mathbf{P}$ \\
\hline Habitat & 1 & 101.63 & $<0.001$ & $13.72 \mid$ & 0.002 & 25.963 & $<0.001$ & 30.970 & $<0.001$ & 0.467 & 0.504 \\
\hline Plant & 1 & 24.481 & $<0.001$ & 3.746 & $0.07 I$ & 1.944 & 0.182 & 26.623 & $<0.001$ & 45.454 & $<0.001$ \\
\hline $\begin{array}{l}\text { Plant part } \\
\text { (PP) }\end{array}$ & 1 & 0.0563 & 0.815 & 0.183 & 0.674 & 21.229 & $<0.001$ & 3.705 & 0.072 & 21.018 & $<0.001$ \\
\hline Habitat $\times$ PP & 1 & 3.510 & 0.079 & 0.0307 & 0.863 & 2.606 & 0.126 & 10.618 & 0.005 & 0.538 & 0.474 \\
\hline $\begin{array}{l}\text { Habitat } \times \\
\text { Plant }\end{array}$ & 1 & 5.249 & 0.036 & 2.253 & 0.153 & 10.499 & 0.005 & 0.484 & 0.497 & 4.901 & 0.042 \\
\hline Plant $\times$ PP & 1 & 1.087 & 0.313 & 0.0479 & 0.830 & 0.0246 & 0.877 & 0.0998 & 0.756 & 7.105 & 0.017 \\
\hline $\begin{array}{l}\text { Habitat } \times \\
\text { Plant } \times \text { PP }\end{array}$ & 1 & 0.505 & 0.488 & 0.121 & 0.732 & $<0.001$ & 0.995 & 1.179 & 0.294 & 14.113 & 0.002 \\
\hline
\end{tabular}

3-way ANOVA for selected parameters. Data for the CFB were arcsin transformed; for planctomycetes, $\mathrm{x}^{1 / 4}$ transformation was used. 
Table 2: Chemical parameters measured in plants

\begin{tabular}{|c|c|c|c|c|c|c|}
\hline & \multicolumn{2}{|c|}{$\begin{array}{l}\text { Total phenolic content } \\
{\left[\mathrm{mg}(\mathrm{g} \text { dry mass })^{-1}\right]}\end{array}$} & \multicolumn{2}{|c|}{$\begin{array}{c}\text { Anthocyanin } \\
{\left[\mathrm{mg} \mathrm{(g} \mathrm{dry} \mathrm{mass)}^{-1}\right]}\end{array}$} & \multicolumn{2}{|c|}{$\begin{array}{l}\text { Chlorophyll } a \text { and } b \\
\left.\text { [mg (g dry mass) })^{-1}\right]\end{array}$} \\
\hline & LC & SB & LC & SB & LC & SB \\
\hline $\begin{array}{l}\text { C. aspera } \\
\text { M. spicatum }\end{array}$ & $0.9 \pm 0.08$ & $0.7 \pm 0.12$ & $0.05 \pm 0$ & $0.06 \pm 0$ & $1.9 \pm 0.17$ & $1.2 \pm 0.02$ \\
\hline Apex & $173 \pm 21$ & $120 \pm 33$ & $0.9 \pm 0.02$ & $0.52 \pm 0.08$ & $6.8 \pm 1.3$ & $2.3 \pm 0.26$ \\
\hline Upper leaves & $120 \pm 29$ & $97 \pm 5$ & $0.8 \pm 0.2$ & $0.50 \pm 0.01$ & $8.4 \pm 2.3$ & $2.3 \pm 0.28$ \\
\hline \multirow[t]{3}{*}{ Upper stem } & $133 \pm 13$ & $100 \pm 9$ & $1.4 \pm 0.1$ & $0.81 \pm 0.15$ & $1.8 \pm 0.6$ & $1.0 \pm 0.04$ \\
\hline & \multicolumn{2}{|c|}{$\frac{C}{\left[m g\left(\text { dry mass }^{-1}\right]\right.}$} & \multicolumn{2}{|c|}{$\stackrel{\mathrm{N}}{\left[\mathrm{mg}(\mathrm{g} \text { dry mass) })^{-1}\right]}$} & \multicolumn{2}{|c|}{$\begin{array}{c}P \\
{\left[\mathrm{mg}\left(\text { (g dry mass) }^{-1}\right]\right.}\end{array}$} \\
\hline & LC & SB & LC & SB & LC & SB \\
\hline $\begin{array}{l}\text { C. aspera } \\
\text { M. spicatum }\end{array}$ & $206 \pm 4$ & $179 \pm 15$ & $11 \pm 1.1$ & $14 \pm 0.12$ & $0.4 \pm 0.1$ & $0.68 \pm 0.06$ \\
\hline Apex & $425 \pm 20$ & $357 \pm 35$ & $36 \pm 9$ & $24 \pm 8$ & $2.6 \pm 1.2$ & $2.4 \pm 1.5$ \\
\hline Upper leaves & $384 \pm 37$ & $363 \pm 5$ & $27 \pm 6$ & $16 \pm 3$ & 1.2 & $1.3 \pm 0.33$ \\
\hline Upper stem & $400 \pm 7$ & $379 \pm 25$ & $15 \pm 3$ & $14 \pm 3$ & $0.9 \pm 0.2$ & -- \\
\hline
\end{tabular}

LC: Lake Constance, SB: Schaproder Bodden, $n=3$, mean \pm SD

habitats. The bacterial abundance in the two habitats and on the different plant parts differed significantly, but did not differ significantly between the two plant species (Figure 2, Table 1). In general, we found higher a bacterial abundance on plants from Schaproder Bodden $\left[5.1 \times 10^{7}\right.$ $\pm 3.9 \times 10^{7}$ cells (g dry mass) $)^{-1}$; mean $\pm 1 \mathrm{SD}$ ] than on plants from Lake Constance $\left[1.3 \times 10^{7} \pm 0.7 \times 10^{7}\right.$ cells ( $\mathrm{g}$ dry mass $)^{-1}$. The lower plants parts from Schaproder Bodden had higher bacterial cell counts than the upper plant parts, while cell counts on lower plant parts from Lake Constance were only marginally higher than the counts on upper plant parts (Figure 2), resulting in a significant habitat $\times$ plant part interaction (Table $1, \mathrm{P}=0.005$ ). The ash-free dry mass differed significantly between habitats, and the organic content of the plant samples differed significantly between habitats and plant species but not between plant parts (Table 1). The general pattern of bacterial abundance remained when calculated on an organic dry matter basis (Figure 2).

The composition of the bacterial biofilm on the two plant species was similar except for the abundance of members of the CFB group and planctomycetes (Figure 3 ). On both plant species in both habitats, bacteria of the CFB group were the most abundant bacterial group and reached up to $35 \%$ of the total cell counts. The CFB counts correlated positively with all measured chemical parameters (Pearson correlation: carbon: $\mathrm{r}=0.637, \mathrm{P}=0.0008$; nitrogen: $\mathrm{r}$ $=0.666, \mathrm{P}=0.0003$; phosphorus: $\mathrm{r}=0.755, \mathrm{P}<0.0001$; chlorophyll: $\mathrm{r}=0.433, \mathrm{P}=0.0344$; total phenolic compounds: $r=0.685, P=0.0002)$. The number of $C F B$ cells was generally higher on $M$. spicatum than on $C$. aspera and higher on upper parts of both plant species. The differences were not uniform and resulted in significant interaction terms (Figure 3; Table 1), which indicated specific habitat, plant, and plant part patterns.

The second major group of bacteria in the biofilms were alphaproteobacteria, which accounted for $3-17 \%$ of the DAPI counts. The abundance of alphaproteobacteria did not differ between plant species and habitats (3-way ANOVA, $\mathrm{df}=1, \mathrm{~F}=4.1, \mathrm{P}=0.05$ ). Beta- and gammaproteobacteria abundance was similar on both plant species and in both habitats (3-way ANOVA, $\mathrm{df}=1, \mathrm{~F}=1.257, \mathrm{P}$ $=0.279 ; \mathrm{df}=1, \mathrm{~F}=1.982, \mathrm{P}=0.178)$. Actinomycetes were the least-abundant group, and their abundance did not differ between plant species (0.7-2.0\% of DAPI counts, 3way ANOVA, $\mathrm{df}=1, \mathrm{~F}=1.179, \mathrm{P}=0.294)$.

Interestingly, the proportion of planctomycetes differed between habitat and plant species. In Lake Constance, almost no planctomycetes were detected on M. spicatum, but they made up 2-3\% of all cell counts on $C$. aspera. In Schaproder Bodden, planctomycetes were found on both plant species, with slightly higher numbers on the upper plant parts $(2-6 \%$ of DAPI counts) than on the lower plant parts, but there were no differences between the plant species (Figure 3, Table 1). We found negative correlations of this group with carbon (Pearson correlation; $r=$ -0.507, $\mathrm{P}=0.0114)$, nitrogen $(\mathrm{r}=-0.433, \mathrm{P}=0.0343)$, chlorophyll $(\mathrm{r}=-0.648, \mathrm{P}=0.0006)$, and total phenolic content $(\mathrm{r}=-0.449, \mathrm{P}=0.0278)$. 


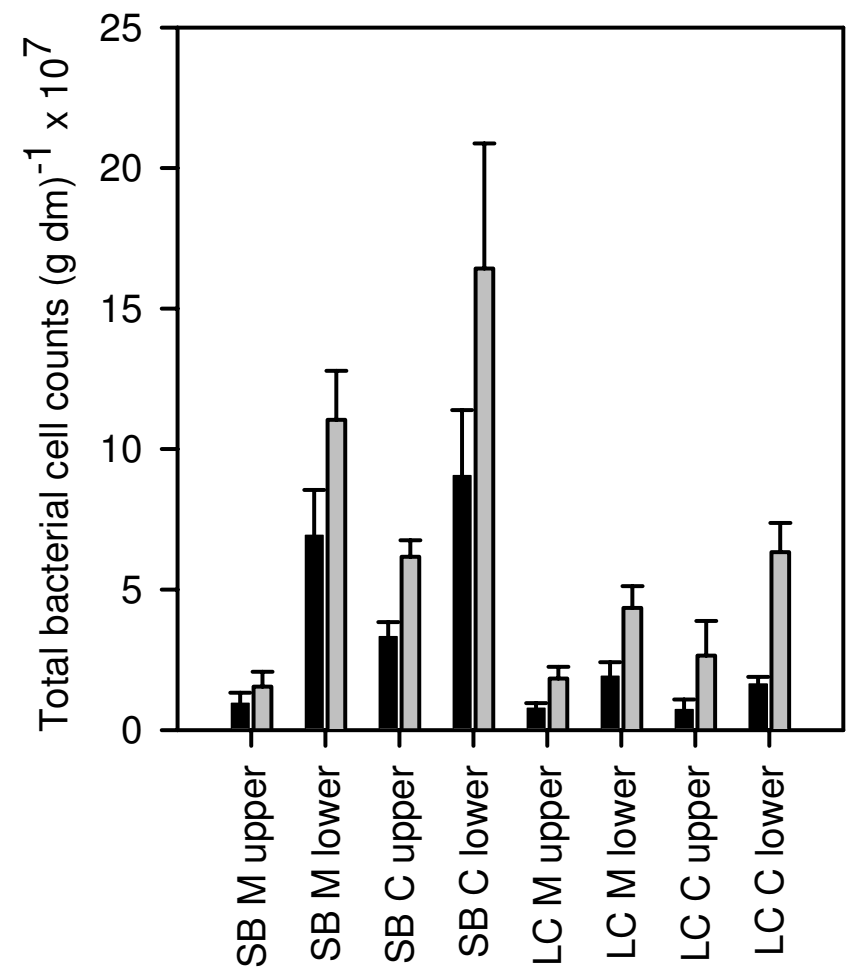

Figure 2

Total bacterial cell counts determined by DAPI staining. Black bars: counts ( $g$ dry mass) $)^{-1}$; grey bars: counts (g ash-free dry mass) ${ }^{-1}$. SB: Schaproder Bodden; LC: Lake Constance; M: M. spicatum; C: $C$. aspera. $n=3$; error bars indicate SE.

Overall, the bacterial community composition on M. spicatum in Lake Constance differed from that on $C$. aspera in both habitats and even from M. spicatum in Schaproder Bodden (Figure 4).

\section{Discussion}

To our knowledge, this is the first study comparing bacterial biofilms on two macrophytes in brackish and freshwater habitats. Our data support the findings of other studies of biofilms on aquatic organisms, especially diatoms and cyanobacteria, where CFB and alphaproteobacteria make up major parts of the biofilm $[8,10]$. The total bacterial cell counts on the two plant species revealed that habitat and plant part seem to be more important for epiphyte bacterial abundance than the plant species. Although surface area-to-dry mass ratios have been determined in other studies, e.g. Myriophyllum spicatum 1205 $\mathrm{cm}^{2}$ (g dry mass) ${ }^{-1}$ and Nitellopsis obtusa (starry stonewort) $560 \mathrm{~cm}^{2}$ (g dry mass)-1 [33], we decided not to calculate bacterial density based on plant surface area because our computer-based image analysis of $M$. spicatum leaf area showed that the calculation of surface area based on dry mass cannot be averaged over the whole plant. The surface area-to-dry mass ratio was $3500 \mathrm{~cm}^{2}(\mathrm{~g}$ dry mass) ${ }^{-1}$ for freshwater $M$. spicatum apices and 1600 $\mathrm{cm}^{2}$ (g dry mass)-1 for the lower parts of the same plant. Such a difference would amplify our findings that lower shoots harbour a higher abundance of bacteria. Freshwater Chara spp. had a surface area-to-biomass ratio of only $122 \mathrm{~cm}^{2}$ (g dry mass)-1, which would yield even higher bacterial densities on this plant. In general, bacterial counts were highest on lower leaves close to the sediment (Figure 2). This seems reasonable since biofilm on older leaves should be thicker, thus containing more cells. Older leaves also contain less allelopathic compounds and are leakier than younger leaves, which might influence the nutrient availability. The nutrient content of the water column could be higher close to the sediment; this could also have an impact, but was not assessed in this study. Differences between the total bacterial cell counts on plant species from the different habitats might also be a consequence of $\mathrm{pH}$, temperature, salinity and water retention time, which have been also found to influence community composition $[34,35]$.

Alpha-, beta-, and gammaproteobacteria were present on both macrophytes in similar abundance, with gammaproteobacteria having the lowest counts of the proteobacteria. The least-abundant group was the actinomycetes (0.7-2.0\% of DAPI counts). Not all members of this group might have been detected with the FISH probes because of the generally thicker cell walls of gram-positive bacteria. Our EUB probe, for example, detected only 50$80 \%$ of all DAPI cell counts (data not shown). The coverage of all bacteria together could probably have been higher if a combination of three different EUB probes were used [36], but since the planctomycetes, which are often missed by the single EUB probe used, did not make up a major amount of the biofilm, our results would not have changed dramatically. The total counts of all groupspecific probes did not account for all eubacterial counts. We therefore assume that we did not detect all bacterial groups present in the biofilm of the two plant species, but we did use probes for the most common groups in biofilms and aquatic systems.

Alpha- and betaproteobacteria are the most abundant bacteria in lake snow aggregates in Lake Constance, and CFB are only found in hypolimnic particles, where they are considered to degrade refractory compounds such as chitin and cellulose [37]. Betaproteobacteria in the polluted river Spittelwasser dominated biofilms formed on glass slides throughout the year, followed by alphaproteobacteria, with seasonal maxima of CFB and planctomycetes, but gammaproteobacteria were never abundant [38]. Comparably, alphaproteobacteria, followed by CFB, were dominant in biofilms on stainless steel and polycarbonate exposed in Delaware Bay, and betaproteobacteria were 


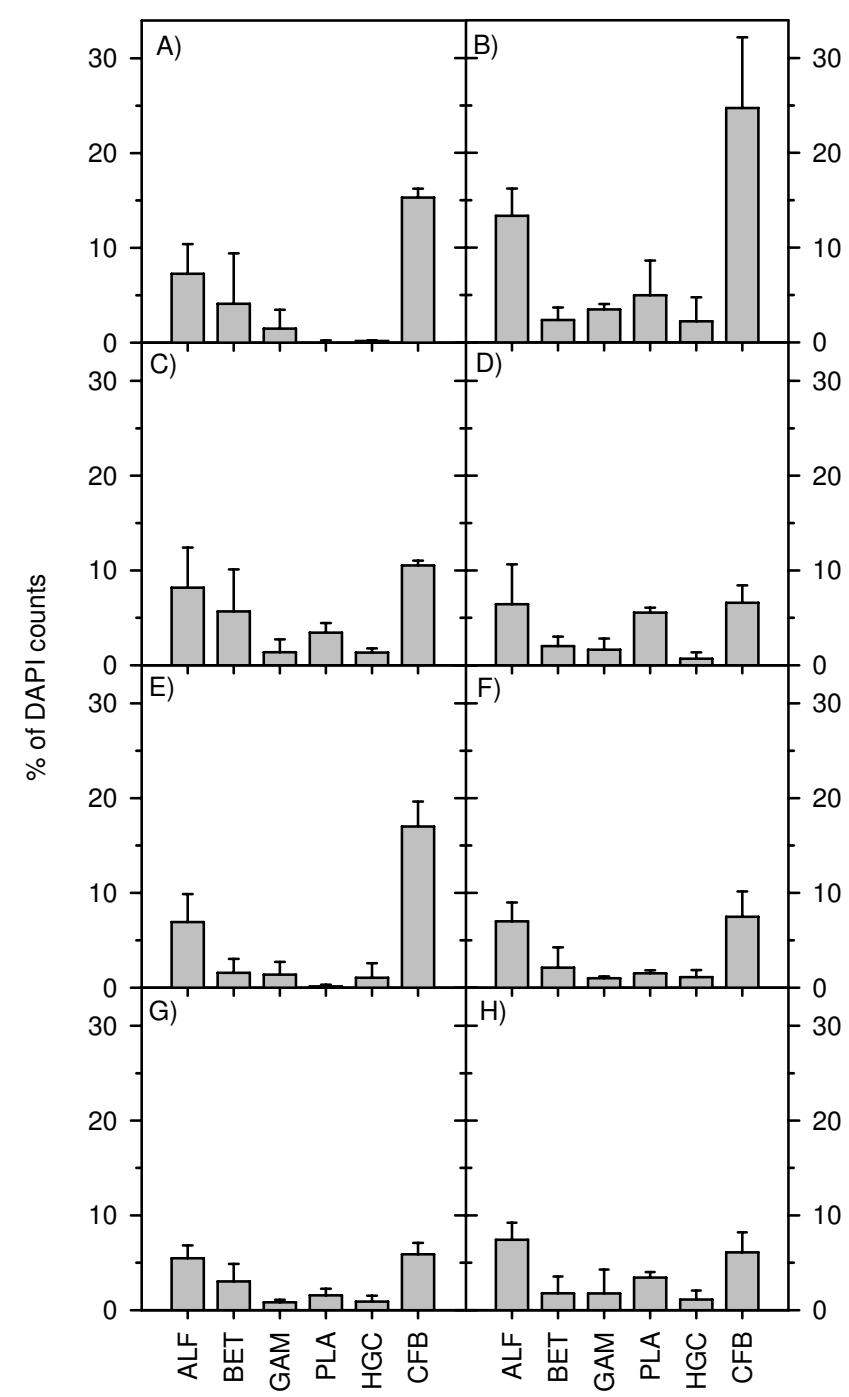

Figure 3

Biofilm composition in Lake Constance (left) and Schaproder Bodden (right). A and B, M. spicatum upper section; $C$ and $D, C$. aspera upper section; $E$ and $F, M$. spicatum lower section; $G$ and $H, C$. aspera lower section. $n=3$; errors bars indicate SD. ALF: alphaproteobacteria; BET: betaproteobacteria; GAM: gammaproteobacteria; PLA: planctomycetes; HGC: actinomycetes; CFB: Cytophaga-

Flavobacteria-Bacteroidetes.

almost absent [39]. In our study, we saw a comparable picture, with CFB mostly dominating the biofilm on macrophytes, followed by alpha- and betaproteobacteria. Distinct differences for habitat and plant species were found for the members of the CFB group and planctomycetes. Especially the abundance of planctomycetes differed between plant species and between the plant parts. Planctomycetes are found in a wide variety of habitats and are known to colonize surfaces [40]. Earlier studies on lake

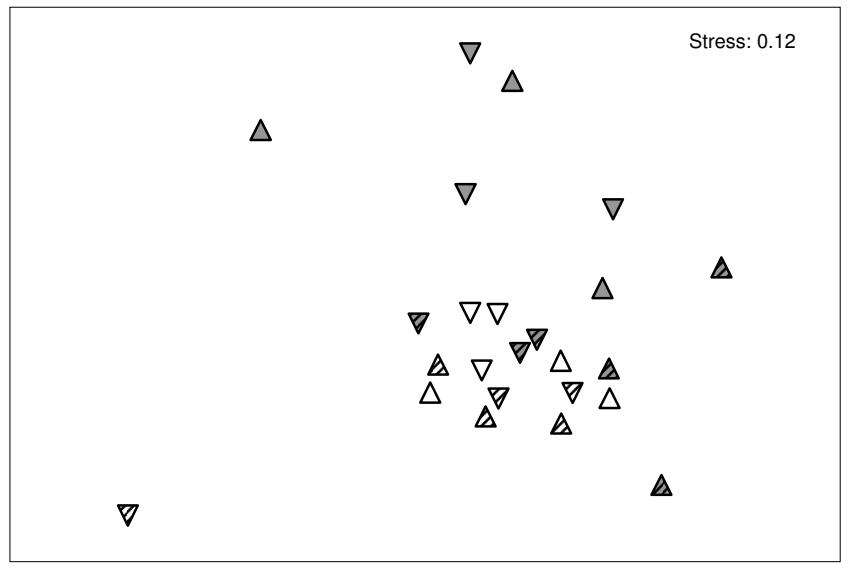

Figure 4

Non-metric dimensional scaling plot of the bacterial community composition on all plant samples. Grey triangles: $M$. spicatum, white triangles: $C$. aspera. Striped triangles: samples from Schaproder Bodden; non-striped triangles: samples from Lake Constance. Upper and lower plant parts are denoted by triangles pointing upwards and downwards, respectively. Data are $x^{1 / 4}$ transformed.

snow in Lake Constance did not look for this bacterial group, and a comparison of lakes and oceans found only low numbers in freshwater and hardly any in the marine bacterioplankton $[5,37]$. The authors of the latter study argue that this might be due to low abundance and that FISH was at the range of its detection limit. This could also be the case in our study since we only found low abundances. Based on our data and the meagre knowledge about planctomycetes ecology, we propose that either nutrient content or plant age (senescence) might account for differences in the abundance of planctomycetes because of the strong negative correlations with carbon, nitrogen, chlorophyll, and total phenolic content. This is supported by a study of marine planctomycetes, which were affected by organic compounds [41], and the observation that $M$. spicatum excretes substantial amounts of organic compounds [42]. Planctomycetes occur in many different habitats, yet their ecology is unexplored since only a few species have been cultivated [43].

The dominance of the CFB group in all our samples is not unusual, but is nevertheless interesting because we found distinct differences between plant species and plant parts. The CFB counts correlated positively with plant carbon and nutrient content as well as with chlorophyll and phenolic compounds. Members of the CFB group have often been described as major components of biofilms and are known to degrade rather complex molecules that occur in the high molecular mass fraction of dissolved organic matter [44]. This is important for other bacterial groups that are not capable of degrading such molecules but 
thrive on the degradation products [24]. Considering that alphaproteobacteria are more likely to degrade labile organic matter $[37,45]$, this group could depend on degradation products of CFB or betaproteobacteria. The correlation of alphaproteobacteria with CFB $(\mathrm{r}=0.444, \mathrm{P}=$ 0.03) might be evidence for this.

We found that habitat had a distinct influence on both planctomycetes and members of the CFB group. The Schaproder Bodden is a shallow coastal area of the Baltic Sea and has a higher salinity than Lake Constance. Salinity is in fact a major environmental determinant of microbial community composition [35]. Whether or not the trophic state of the habitat influences biofilm density and composition remains open. Epiphytic algae are influenced by the trophic state, especially nitrogen availability, but only indirectly or not at all by host species [46]. Under eutrophic conditions, epiphytes should receive more organic and inorganic resources from the surrounding water and should be less dependent on plant-exuded compounds. It is unlikely that plant nutrient content influences the algal biofilm since plants relocate only small amounts of macronutrients [20]. This, however, does not exclude the possibility that the epiphytic algal composition might influence the composition of heterotrophic bacteria.

Only M. spicatum from Lake Constance exhibited a distinct bacterial biofilm community compared to M. spicatum from Schaproder Bodden and $C$. aspera from both habitats (Figure 4). Perhaps the phenolic content of the plant species in the different habitats is responsible for this effect. While $C$. aspera contains almost no phenolic compounds, M. spicatum has high concentrations of total phenolic compounds and anthocyanin, especially in the samples from Lake Constance.

We propose that the bacterial community composition is rather determined by the presence or (near) absence of phenolic compounds and not by their concentrations, since the concentrations between the upper and lower shoots in both habitats are rather similar. The association of polyphenol-degrading bacteria with M. spicatum [47] might be evidence for this. A direct proof of the impact of phenolic compounds on biofilm composition is difficult to achieve, and complex molecules, especially tannins, can be a difficult substrate for some bacteria [19] and may have caused this pattern. We also cannot rule out other factors such as salinity, $\mathrm{pH}$, temperature, and dissolved organic carbon to explain these differences [48]. Dissolved organic matter produced by plants and epiphytic algae is usually subjected to photolysis [49] but can also be degraded by bacteria capable of degrading high molecular weight compounds [44]. The resulting degradation products as well as carbon dioxide and oxygen recycling can be of mutual benefit for both primary producers and heterotrophic bacteria. Biofilm bacteria are also known to produce compounds that can influence phototrophs beneficially or detrimentally [25]. Both plant species contain allelochemicals known to inhibit bacterial or algal growth $[16,50]$.

\section{Conclusion}

We present one of the first studies investigating heterotrophic bacterial communities on aquatic plants. To elucidate further which bacterial groups are active and contribute metabolically to processes within the biofilm, further approaches such as MICRO-FISH could be applied. To gain insight into the bacterial groups involved more specific probes for proteobacteria and CFB should be used. Also archaea could be of interest since they play a major role in the root region of various aquatic plants. Our data suggest an apparent impact of plant species, plant age and habitat on epiphytic bacterial communities.

\section{Methods \\ Plants}

Brackish water samples of Chara aspera and MyriophylIum spicatum were collected on 24 October 2006 in the Schaproder Bodden, east of the Isle of Hiddensee ( $\mathrm{N}$ $\left.54^{\circ} 27.4627^{\prime} ; \mathrm{E} 13^{\circ} 07.5664^{\prime}\right)$. Three plants each were collected by snorkelling in $0.7-1 \mathrm{~m}$ depth, stored in artificial brackish water $(8 \%$, the same salinity as in the Bodden;[51]) with $3.5 \%$ formaldehyde (final concentration). Freshwater plants were sampled at the southwest shore of the Isle of Reichenau, Lake Constance, near a gravel ridge ( $\left.\mathrm{N} 47^{\circ} 42.247, \mathrm{E} 9^{\circ} 02.289\right)$. Three replicates each were collected on 6 November 2006 at a depth of $0.7-1.2 \mathrm{~m}$ for M. spicatum and 2.5-3 $\mathrm{m}$ for $C$. aspera. The plants were transported in separate sterile tubes to the laboratory, where they were fixed with 3.5\% formaldehyde (final concentration). All samples were stored at $4{ }^{\circ} \mathrm{C}$ until processing started on 7 November 2006. The plant samples were divided into an upper section of the plants apices, approx. $5 \mathrm{~cm}$ long, and a lower section, approximately $5-10 \mathrm{~cm}$ of stem length above the sediment.

\section{Biomass and chemical analyses}

Myriophyllum spicatum was processed as part of our routine sampling campaign, in which plants are dissected into apices, upper and lower leaves, and stems. For $C$. aspera chemical analyses, we did not differentiate between upper and lower plant parts. Sub-samples of each plant part were incinerated for $6 \mathrm{~h}$ at $550^{\circ} \mathrm{C}$ to determine the ash-free dry mass. We measured the carbon, nitrogen, and phosphorus content of all plant samples using standard methods [52]. The total phenolic content of $M$. spicatum and $C$. aspera was determined using a modified Folin-Ciocalteau method [53]. The concentration of non-phenolic compounds interfering 
Table 3: Oligonucleotide probes used in this study

\begin{tabular}{|c|c|c|c|c|}
\hline Probea) & Sequence & \% Formamide & Target group & Reference \\
\hline EUB338 & GCTGCCTCCCGTAGGAGT & 35 & Most bacteria & [58] \\
\hline NON338 & ACTCCTACGGGAGGCAGC & 35 & Competitor of EUB & [59] \\
\hline ALF968 & GGTAAGGTTCTGCGCGT & 20 & Alphaproteobacteria & [60] \\
\hline BET42ab) & GCCTTCCCACTTCGTTT & 35 & Betaproteobacteria & [61] \\
\hline GAM42ab) & GCCTTCCCACATCGTTT & 35 & Gammaproteobacteria & {$[61]$} \\
\hline PLA886'b) & GCCTTGCGACCATACTCCC & 35 & Planctomycetes & [62] \\
\hline HGC96a & TATAGTTACCACCGCCGT & 25 & Actinomycetes & [63] \\
\hline CF3I9a & TGGTCCGTGTCTCAGTAC & 35 & Bacteroidetes & [64] \\
\hline
\end{tabular}

a) Probes were labelled with cy 3 b) For these probes, a competitor probe was used

with the Folin reagent are $<5 \%$ in $M$. spicatum [52]. Those in $C$. aspera were determined using a modified polyvinylpyrrolidon method [50]. The major allelochemical of $M$. spicatum, tellimagrandin II, was quantified by reverse-phase HPLC [47]. All measurements were based on dry mass since the inorganic incrustations of $C$. aspera also provide settlement surfaces for bacteria. The antibacterial and allelopathically active compounds in Chara spp. $[11,14]$ are difficult to isolate and were not determined here.

\section{Detachment of biofilm}

Plant parts were transferred into sterile $50 \mathrm{ml}$ polypropylene tubes containing $50 \mathrm{ml}$ of formaldehyde (3.7\% final concentration) and sodium pyrophosphate $(0.1 \mathrm{M}$ $\left.\mathrm{Na}_{4} \mathrm{P}_{2} \mathrm{O}_{7} \times 10 \mathrm{H}_{2} \mathrm{O}, \mathrm{NaPPi}\right)$. The biofilm was detached by ultrasonication for $60 \mathrm{~s}$ (Laboson 200 ultrasonic bath, Bender \& Hobein), followed by 15 min of vigorous shaking (18.3 Hz, Thermomixer Eppendorf) and again $60 \mathrm{~s}$ of ultrasonication. Two millilitres of the detached biofilm were filtered onto white polycarbonate filters $(0.2 \mu \mathrm{m}, \varnothing$ $25 \mathrm{~mm}$ Nucleopore) and stored at -20 C.

We optimized the detachment procedure prior to this experiment. NaPPi was a suitable detergent to detach bacteria from macrophyte leaves as shown by a previous study in our group [47]. We further varied the sonication time and shaking duration to obtain the best results for a gentle but effective detachment of the biofilm [54,55]. Detachment with an ultrasonic probe (Bandelin electronic GM $70 \mathrm{HD}, 20 \mathrm{kHz}, 57 \mathrm{~W}$ ) resulted in $0.13 \pm 0.03 \times$ $10^{6} \mathrm{~cm}^{-2}$ but the plant tissue was severely damaged and numerous bacterial cells were still attached to the leaf surface as observed by microscopic examination. We then tried are more gentle detachment with shorter sonication times in an ultrasonic bath and constant, gentle shaking afterwards, rather than permanent ultrasonication. This method yielded $1.9 \pm 0.6 \times 10^{6}$ cells $\mathrm{cm}^{-2}$ and the plant tissue was not visibly damaged except at the cut surface on the petiole. A thorough microscopy of the leaves proved hardly any attached bacterial cells left.
Fluorescence in situ hybridization (FISH)

FISH was conducted following a protocol by Pernthaler et al. [56] consisting of a hybridization step at $46^{\circ} \mathrm{C}$ for $3 \mathrm{~h}$ and a washing step for $15 \mathrm{~min}$ at $48^{\circ} \mathrm{C}$. Filters were counterstained with DAPI (4',6-diamidino-2-phenylindol, 1 $\left.\mu \mathrm{g} \mathrm{ml}{ }^{-1}, 5 \mathrm{~min}\right)$. Stained cells were counted under an epifluorescence microscope (Labophot 2, Nikon) at an excitation wavelength of $549 \mathrm{~nm}$. Probes used are listed in Table 3 and further details are available at probeBase [57].

\section{Statistical analyses}

Data of FISH analysis we re arcsin transformed. For planctomycetes, data were additionally $\mathrm{x}^{1 / 4}$ transformed to ensure equal variances. Plant species-, plant part-, and habitat-specific differences were analysed by 3-way ANOVAs (Sigma STAT 3.0). Non-metric dimensional scaling plots were generated with square-root transformation of data and Bray-Curtis similarity (Primer 5.0). For correlations, the Pearson correlation was used (Sigma STAT 3.0).

\section{Authors' contributions}

$\mathrm{MH}$ : Guidance of experiments; writing the manuscript

MB: Carried out sampling and experiments

IB: Initiated the work on biofilm on charophytes together with $\mathrm{MB}$, critically amended and edited the manuscript

EMG: Sampling in Lake Constance, supervising experiments, writing and editing the manuscript

All authors read and approved the final manuscript.

\section{Acknowledgements}

This work was supported by the German Science Foundation with grant CRC454, project A2 to EMG. Claudia Feldbaum is acknowledged for technical assistance. We thank M. Mörtl for providing the statistical program PRIMER 5. Karen Brune improved the English, and two anonymous reviewers made valuable comments on the manuscript.

\section{References}

I. Costerton JW, Lewandowski Z, Caldwell DE, Korber DR, Lappinscott HM: Microbial Biofilms. Annu Rev Microbiol 1995, 49:7II-745. 
2. Stanley NR, Lazazzera BA: Environmental signals and regulatory pathways that influence biofilm formation. Mol Microbiol 2004, 52(4):917-924.

3. Jasti S, Sieracki ME, Poulton NJ, Giewat MW, Rooney-Varga JN: Phylogenetic diversity and specificity of bacteria closely associated with Alexandrium spp. and other phytoplankton. Appl Environ Microbiol 2005, 7 I (7):3483-3494.

4. Weiss $P$, Schweitzer B, Amann R, Simon M: Identification in situ and dynamics of bacteria on limnetic organic aggregates (Lake Snow). Appl Environ Microbiol 1996, 62(6): I998-2005.

5. Glockner FO, Fuchs BM, Amann R: Bacterioplankton compositions of lakes and oceans: a first comparison based on fluorescence in situ hybridization. Appl Environ Microbiol 1999, 65(8):372I-3726.

6. Shade A, Kent AD, Jones SE, Newton RJ, Triplett EW, McMahon KD: Interannual dynamics and phenology of bacterial communities in a eutrophic lake. Limnol Oceanogr 2007, 52(2):487-494.

7. Sapp M, Wichels A, Wiltshire KH, Gerdts G: Bacterial community dynamics during the winter-spring transition in the North Sea. FEMS Microbiol Ecol 2007, 59(3):622-637.

8. Eiler A, Bertilsson S: Composition of freshwater bacterial communities associated with cyanobacterial blooms in four Swedish lakes. Environ Microbiol 2004, 6( I 2): 1 228-1243.

9. Riemann L, Steward GF, Azam F: Dynamics of bacterial community composition and activity during a mesocosm diatom bloom. Appl Environ Microbiol 2000, 66(2):578-587.

10. Grossart HP, Levold F, Allgaier M, Simon M, Brinkhoff T: Marine diatom species harbour distinct bacterial communities. Environ Microbiol 2005, 7(6):860-873.

I I. Fisher MM, Wilcox LW, Gram LE: Molecular characterization of epiphytic bacterial communities on charophycean green algae. Appl Environ Microbiol I998, 64( I I):4384-4389.

12. Pernthaler J, Amann R: Fate of heterotrophic microbes in pelagic habitats: Focus on populations. Microbiol Mol Biol Rev 2005, 69(3):440-46I.

13. Simon M, Grossart HP, Schweitzer B, Ploug H: Microbial ecology of organic aggregates in aquatic ecosystems. Aquat Microb Ecol 2002, 28(2): 175-2II.

14. Scheffer M, Hosper SH, Meijer ML, Moss B, Jeppesen E: Alternative equilibria in shallow lakes. Trends Ecol Evol 1993, 8:275-279.

15. Nakai S, Inoue Y, Hosomi M, Murakami A: Myriophyllum spicatumreleased allelopathic polyphenols inhibiting growth of bluegreen algae Microcystis aeruginosa. Water Res 2000, 34(I I):3026-3032.

16. Wium-Andersen S, Anthoni U, Christophersen C: Allelopathic effects on phytoplankton by substances isolated from aquatic macrophytes (Charales). Oikos 1982, 39:187-190.

17. Anthoni U, Nielsen PH, Smithhansen L, Wium-Andersen S, Christophersen C: Charamin, a quaternary ammonium ion antibiotic from the green-alga Chara globularis. J Org Chem 1987, 52(4):694-695.

18. Leu E, Krieger-Liszkay A, Goussias C, Gross EM: Polyphenolic allelochemicals from the aquatic angiosperm Myriophyllum spicatum inhibit photosystem II. Plant Physiol 2002, 130:201 I-2018.

19. Scalbert A: Antimicrobial properties of tannins. Phytochemistry I991, 30(I 2):3875-3883.

20. Carignan R, Kalff J: Phosphorus release by submerged macrophytes: Significance to epiphyton and phytoplankton. Limnol Oceanogr 1982, 27(3):419-427.

21. Jackson LJ, Rowan DJ, Cornett RJ, Kalff J: Myriophyllum spicatum pumps essential and nonessential trace elements from sediments to epiphytes. Can J Fish Aquat Sci I 994, 5 I (8): I769-I 773.

22. Sondergaard $\mathrm{M}$ : Kinetics of extracellular release of ${ }^{14} \mathrm{C}$-labelled organic carbon by submersed macrophytes. Oikos 1981, 36(3):331-347.

23. Huss AA, Wehr JD: Strong indirect effects of a submersed aquatic macrophyte, Vallisneria americana, on bacterioplankton densities in a mesotrophic lake. Microb Ecol 2004, 47(4):305-315.

24. Wetzel RG: Microcommunities and microgradients: Linking nutrient regeneration, microbial mutualism and high sustained aquatic primary production. NL J Aquat Ecol 1993, 27(I):3-9

25. Rao D, Webb JS, Kjelleberg S: Microbial colonization and competition on the marine alga Ulva australis. Appl Environ Microbiol 2006, 72(8):5547-5555.
26. Marshall K, Joint I, Callow ME, Callow JA: Effect of marine bacterial isolates on the growth and morphology of axenic plantlets of the green alga Ulva linza. Microb Ecol 2006, 52(2):302-310.

27. Matsuo $Y$, Imagawa H, Nishizawa M, Shizuri $Y$ : Isolation of an algal morphogenesis inducer from a marine bacterium. Science 2005, 307(57I5): I598.

28. Huber B, Eberl L, Feucht W, Polster J: Influence of polyphenols on bacterial biofilm formation and quorum-sensing. Z Naturforsch Sect CJ Biosci 2003, 58( I |- | 2):879-884.

29. Maximilien R, de Nys R, Holmstrom C, Gram L, Givskov M, Crass K, Kjelleberg S, Steinberg PD: Chemical mediation of bacterial surface colonisation by secondary metabolites from the red alga Delisea pulchra. Aquat Microb Ecol 1998, I 5(3):233-246.

30. Rasmussen TB, Manefield M, Andersen JB, Eberl L, Anthoni U, Christophersen C, Steinberg P, Kjelleberg S, Givskov M: How Delisea pulchra furanones affect quorum sensing and swarming motility in Serratia liquefaciens MG I. Microbiology 2000, I 46:3237-3244.

31. Dobretsov S, Dahms HU, Huang YL, Wahl M, Qian PY: The effect of quorum-sensing blockers on the formation of marine microbial communities and larval attachment. FEMS Microbiol Ecol 2007, 60(2): I77-I88.

32. Chand T, Harris RF, Andrews JH: Enumeration and characterization of bacterial colonists of a submersed aquatic plant, Eurasian watermilfoil (Myriophyllum spicatum L.). Appl Environ Microbiol 1992, 58( I 0):3374-3379.

33. Sher-Kaul S, Oertli B, Castella E, Lachavanne JB: Relationship between biomass and surface-area of six submerged aquatic plant-species. Aquat Bot 1995, 5 I (I-2): |47-I54.

34. Lindstrom ES, Kamst-Van Agterveld MP, Zwart G: Distribution of typical freshwater bacterial groups is associated with $\mathbf{p H}$, temperature, and lake water retention time. Appl Environ Microbiol 2005, 7 I( I 2):820 I-8206.

35. Lozupone CA, Knight R: Global patterns in bacterial diversity. PNAS 2007, I 04(27): I | 436- | | 440.

36. Daims H, Bruhl A, Amann R, Schleifer KH, Wagner M: The domainspecific probe EUB338 is insufficient for the detection of all Bacteria: development and evaluation of a more comprehensive probe set. Syst Appl Microbiol 1999, 22(3):434-444

37. Schweitzer B, Huber I, Amann R, Ludwig W, Simon M: Alpha- and beta-proteobacteria control the consumption and release of amino acids on lake snow aggregates. Appl Environ Microbiol 200I, 67(2):632-645.

38. Brummer IH, Felske AD, Wagner-Dobler I: Diversity and seasonal changes of uncultured Planctomycetales in river biofilms. Appl Environ Microbiol 2004, 70(9):5094-5I0I.

39. Jones PR, Cottrell MT, Kirchman DL, Dexter SC: Bacterial community structure of biofilms on artificial surfaces in an estuary. Microb Ecol 2007, 53(I): I53-162.

40. Brummer IH, Fehr W, Wagner-Dobler I: Biofilm community structure in polluted rivers: abundance of dominant phylogenetic groups over a complete annual cycle. Appl Environ Microbiol 2000, 66(7):3078-3082.

4I. Tadonleke RD: Strong coupling between natural Planctomycetes and changes in the quality of dissolved organic matter in freshwater samples. FEMS Microbiol Ecol 2007, 59(3):543-555.

42. Godmaire H, Nalewajko C: Growth, photosynthesis, and extracellular organic release in colonized and axenic Myriophyllum spicatum. Can J Bot 1989, 67:3429-3438.

43. Wang J, Jenkins C, Webb RI, Fuerst JA: Isolation of Gemmata-like and Isosphaera-like planctomycete bacteria from soil and freshwater. Appl Environ Microbiol 2002, 68(I):417-422.

44. Kirchman DL: The ecology of Cytophaga-Flavobacteria in aquatic environments. FEMS Microbiol Ecol 2002, 39(2):91-100.

45. Cottrell MT, Kirchman DL: Natural assemblages of marine proteobacteria and members of the Cytophaga-Flavobacter cluster consuming low- and high-molecular-weight dissolved organic matter. Appl Environ Microbiol 2000, 66(4): I692-I697.

46. Phillips GL, Eminson D, Moss B: Mechanism to account for macrophyte decline in progressively eutrophicated freshwaters. Aquat Bot 1978, 4(2): 103-I26.

47. Muller N, Hempel M, Philipp B, Gross EM: Degradation of gallic acid and hydrolysable polyphenols is constitutively activated in the freshwater plant-associated bacterium Matsuebacter sp FB25. Aquat Microb Ecol 2007, 47(I):83-90. 
48. Allgaier M, Grossart HP: Seasonal dynamics and phylogenetic diversity of free-living and particle-associated bacterial communities in four lakes in northeastern Germany. Aquat Microb Ecol 2006, 45(2): II5- I28.

49. Wetzel RG, Hatcher PG, Bianchi TS: Natural photolysis by ultraviolet irradiance of recalcitrant dissolved organic matter to simple substrates for rapid bacterial metabolism. Limnol Oceanogr 1995, 40(8): I 369-1380.

50. Gross EM, Meyer H, Schilling G: Release and ecological impact of algicidal hydrolysable polyphenols in Myriophyllum spicatum. Phytochemistry 1996, 4I(I): 133-138.

5I. Blindow I, Dietrich J, Mollmann N, Schubert H: Growth, photosynthesis and fertility of Chara aspera under different light and salinity conditions. Aquat Bot 2003, 76(3):213-234.

52. Choi C, Bareiss C, Walenciak O, Gross EM: Impact of polyphenols on growth of the aquatic herbivore Acentria ephemerella. J Chem Ecol 2002, 28(I I ):2245-2256.

53. Box JD: Investigation of the Folin-Ciocalteau phenol reagent for the determination of polyphenolic substances in natural waters. Water Res 1983, 17(5):5 II-525

54. Bockelmann U, Szewzyk U, Grohmann E: A new enzymatic method for the detachment of particle associated soil bacteria. J Microbiol Methods 2003, 55(I):20I-2II.

55. Buesing N, Gessner MO: Comparison of detachment procedures for direct counts of bacteria associated with sediment particles, plant litter and epiphytic biofilms. Aquat Microb Ecol 2002, 27(I):29-36.

56. Pernthaler J, Glöckner FO, Schonhuber W, Amann R: Fluorescence in situ hybridization (FISH) with rRNA-targeted oligonucleotide probes. Methods in Microbiology 200I, 30:207-226.

57. Loy A, Horn M, Wagner M: probeBase: an online resource for rRNA-targeted oligonucleotide probes. Nucleic Acids Res 2003, $3 I(I): 5|4-5| 6$.

58. Amann RI, Binder BJ, Olson RJ, Chisholm SW, Devereux R, Stahl DA Combination of I6S rRNA-targeted oligonucleotide probes with flow cytometry for analyzing mixed microbial populations. Appl Environ Microbiol 1990, 56(6): 1919-1925.

59. Wallner G, Amann R, Beisker W: Optimizing fluorescent in situ hybridization with rRNA-targeted oligonucleotide probes for flow cytometric identification of microorganisms. Cytometry 1993, 14(2): 136-143.

60. Neef A: Anwendung der In-situ-Einzelzell-Identifizierung von Bakterien zur Populationsanalyse in komplexen mikrobiellen Biozönosen. In PhD thesis Munich: Technical University Munich, Biology Department; 1997.

6I. Manz W, Amann R, Ludwig W, Wagner M, Schleifer KH: Phylogenetic oligodeoxynucleotide probes for the major subclasses of proteobacteria - problems and solutions. Syst Appl Microbio 1992, I 5(4):593-600.

62. Neef A, Amann R, Schlesner H, Schleifer $\mathrm{KH}$ : Monitoring a widespread bacterial group: in situ detection of planctomycetes with I6S rRNA-targeted probes. Microbiology 1998, 144(Pt I 2):3257-3266.

63. Roller C, Wagner M, Amann R, Ludwig W, Schleifer KH: In situ probing of gram-positive bacteria with high DNA G + C content using $23 S$ rRNA-targeted oligonucleotides. Microbiology 1994, I 40(10):2849-2858

64. Manz W, Amann R, Ludwig W, Vancanneyt M, Schleifer KH: Application of a suite of I6S rRNA-specific oligonucleotide probes designed to investigate bacteria of the phylum cytophagaflavobacter-bacteroides in the natural environment. Microbiology 1996, I42(5): 1097-II06.
Publish with Bio Med Central and every scientist can read your work free of charge

"BioMed Central will be the most significant development for disseminating the results of biomedical research in our lifetime. "

Sir Paul Nurse, Cancer Research UK

Your research papers will be:

- available free of charge to the entire biomedical community

- peer reviewed and published immediately upon acceptance

- cited in PubMed and archived on PubMed Central

- yours - you keep the copyright
BioMedcentral 